\title{
SOME PIONEERS OF THE PAST IN NEUROLOGY*
}

\author{
by \\ SIR ARTHUR MAcNALTY, K.c.B.
}

TODAy the lessons of neuro-physiology and neurology, the anatomy of nerve centres and nerve fibres, the localization of a cerebral tumour or abscess and the results of cerebral and spinal lesions, as shown by paralysis, are so much a part of cerebral teaching and practice, that it is difficult for the modern medical student to realize that until the closing years of the nineteenth century much of the anatomy and physiology of the brain and spinal cord was unknown territory. It is of my own recollections of some of the pioneers of those days that you wish me to speak to you.

\section{Sir Fames Crichton-Browne}

Sir James Crichton-Browne, M.D.Edin., F.R.S. (1840-1937), like his father, specialized in mental diseases, and achieved a high reputation as Medical Director of the West Riding Asylum and editor of the West Riding Asylum Reports which embodied original researches by himself and his pupils on mental disease and neuro-physiology. He was later the Lord Chancellor's Visitor in Lunacy. A man of small stature he retained the long drooping Dundreary whiskers of Victorian days. As a nonagenarian his shrewd eyes were not dim nor his mental powers abated. He was a great orator and spoke in rolling, impressive periods, a mighty voice out of a little body. I first met him in I924 when I gave a Chadwick Lecture on Encephalitis Lethargica at the Royal Society of Medicine and he proposed a vote of thanks. In 1935 he took the chair at a lecture at the United Service Institution on my investigations of epidemic poliomyelitis. I visited him at his house in Hans Place in the last years of his life. He expressed a wish that I should write his life and offered to give me information for it. But by then he was nearly ninety-seven, and both his relatives and $I$ considered that the strain of recalling past memories would be too much for him. Formerly, in addition to his scientific writings, he had published several interesting books of anecdotes, both grave and gay. He was a great raconteur and a wit. His only son, Colonel H. W. A. F. Crichton-Browne, saw much military service and was also a famous mountain explorer. He died a septuagenarian before his father. Shortly before this a friend at the Athenaeum inquired as to the Colonel's health. Sir James shook his head sadly. 'Failing, failing; old age you know, old age.' He was then in his ninety-sixth year. The debt that modern neurology owes to this pioneer is immense.

*Abstract of a Lecture delivered at the National Hospital for Nervous Diseases, Queen Square, London, on 12 November, 1964 . 


\section{E. Brown-Séquard}

This pioneer I never met, but he must be mentioned, for his name and fame adorned the National Hospital. Dr. Gooddy in a recent paper to the Section of the History of Medicine, Royal Society of Medicine, ${ }^{1}$ has given us such an excellent account of this great neurologist's life-work that here only a sketch of his career is necessary. Charles Edouard Brown-Séquard, M.D. Paris, F.R.C.P., F.R.S. (1817-94) was born in Mauritius. By transections and hemisections of the spinal cord he proved that the nerve fibres transmitting pain and temperature sensation do not lie in the posterior columns but cross to take up a position antero-laterally. In 1860 he practised in London and was appointed one of the first physicians to the National Hospital. In spite of success as a consultant, in 1864 he went to Harvard as professor of physiology and nervous pathology. He ended his career as Claude Bernard's successor in the chair of experimental pathology at the Collège de France, and devoted his last years to researches which initiated the science of endocrinology.

\section{Fohn Hughlings Fackson}

John Hughlings Jackson, M.D., F.R.C.P., F.R.S. (I835-I9II) was elected in 1862 physician to the National Hospital. In the following year he was appointed physician to the London Hospital. Henry Head said that Jackson's work at these hospitals made him 'the greatest scientific clinician of the nineteenth century in this country'. He showed how a clinical physician of imagination can draw conclusions which later discoveries in science confirm. From his observations on Jacksonian epilepsy and other observations on chorea and forms of paralysis resulting from local destructive lesions of the cerebral hemispheres, he concluded that movements were represented, or co-ordinated, in some special region of the cerebral cortex. The convulsions arising unilaterally he attributed to discharge of energy from a focus of cortical cells usually due to some gross local lesion. For recent appreciations of Jackson's work generally I would refer you to the Gowers Memorial lecture of ig6o by Sir Charles Symonds ${ }^{2}$ and to Dr. Macdonald Critchley's Centennial Oration of the Institute of Neurology of the same year. ${ }^{3}$

In 1904 or 1905 I met Hughlings Jackson in Sir Victor Horsley's laboratory at University College, London. While he was waiting he looked at some sections of the cerebellum which I was preparing and remarked that functional levels were least specialized in the cerebellum and most specialized in the cerebrum. He then became immersed in a yellow-backed novel which he was reading until Sir Victor and Dr. R. H. Clarke arrived. Jackson watched the experiment with great attention but made no comment. I saw him off in a hansom already resuming his novel. I met him twice afterwards, and it is a precious memory to have conversed with 'the beloved father of English neurology'.

\section{Sir David Ferrier}

Sir David Ferrier, M.D.Edin., F.R.C.P., F.R.S. (1843-1928) was physician to King's College Hospital and physician to the National Hospital. His pioneer 

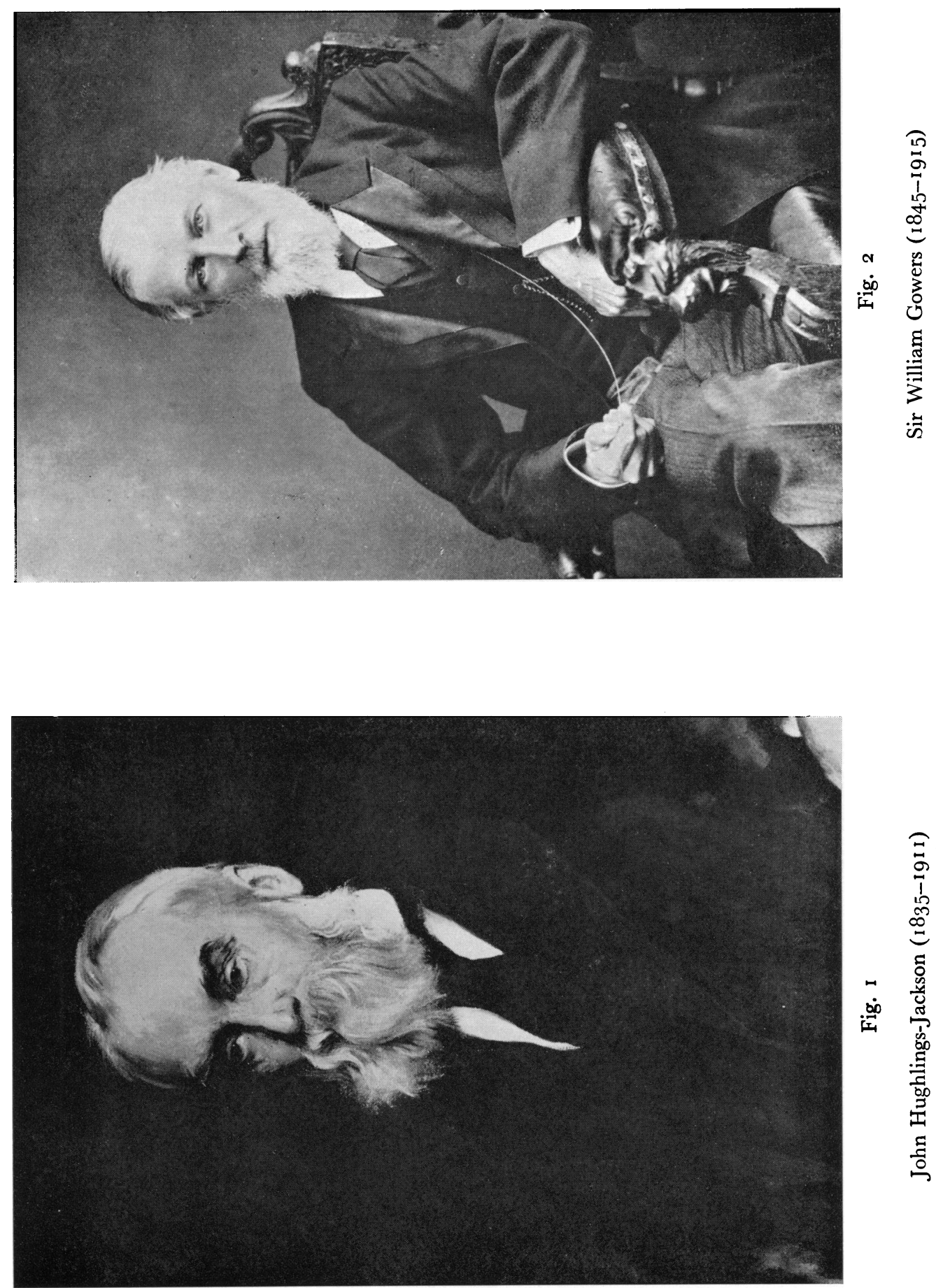

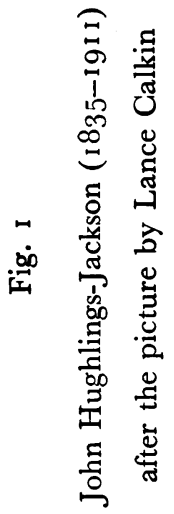




\section{Some Pioneers of the Past in Neurology}

work on cerebral localization was done at the suggestion of Sir James CrichtonBrowne at the West Riding Asylum and at King's College, London. It confirmed and extended the work of Fritsch and Hitzig and confirmed experimentally many of Hughlings Jackson's clinical observations.

In 1926, at the Royal College of Physicians, I was introduced to a thin old gentleman with grey side whiskers, the great Sir David Ferrier. A few weeks' later I met him one Sunday morning in Kensington Gardens and we renewed our acquaintance. Thereafter, until 1928 when his health began to fail, it became a regular custom for us to meet in the Gardens on Sunday mornings; and to pace the Flower Walk together discussing neurology. Ferrier's mind was as alert as ever, and he kept himself informed of modern advances. He adhered to his original interpretation that individual muscles were represented in the cerebral cortex. Hughlings Jackson, on the other hand, said: 'The cerebral cortex knows nothing of muscles, it knows only of movements.' Ferrier, although greatly appreciative of Jackson's work on this subject regarded his views as too speculative. Clinical observations tend to confirm Jackson's reading of the problem.

\section{Sir Charles Sherrington}

Sir Charles Scott Sherrington, O.M., G.B.E., M.D.Cantab., F.R.S. (formerly P.R.S. and Professor of Physiology at Oxford) (1857-I952), I often met either in Oxford or London. In his last years, crippled with arthritis in a nursing home at Eastbourne, his mind remained vigorous; and up to the end of his long life we corresponded from time to time. He was kind and gentle in disposition, a poet and a scholar. My friend, Professor John Fulton of Yale, described Sherrington as 'the most profound student of the nervous system the world has yet known'. Sherrington made clear the mechanism responsible for integrating the individual units of the nervous system; and by so doing helped to establish modern knowledge of the brain and spinal cord, a path which Sir Henry Dale and Lord Adrian, a former R.M.O. of this Hospital have further illuminated.

\section{University College Hospital and the National Hospital}

There was a close link between University College Hospital and the National Hospital. Neuro-surgery began in University College Hospital. In I884 Rickman John Godlee, nephew of Lord Lister and his biographer, was the first surgeon to remove a cerebral tumour which Dr. A. Hughes-Bennett had diagnosed. Unfortunately, the patient died afterwards from septic complications. Sir Rickman Godlee, Bart., a president of the Royal College of Surgeons, was an excellent general surgeon and teacher. I was his dresser and later his housesurgeon. Tall and lean with grey side-whiskers and a quiet sense of humour, he was a strong believer in antiseptic surgery and the use of carbolic, in contrast to his colleague, Arthur Barker, who advocated asepsis and spinal anaesthesia in selected cases. Barker was also a pioneer in cerebral surgery, for he performed the first successful operation in England in 1886 for a cerebral abscess. I also met Sir William Macewen at Horsley's house. Macewen operated for a 
tempero-sphenoidal lobe abscess in 1881 , but it had already infected the lateral ventricle and the patient died.

\section{Sir Victor Horsley}

Sir Victor Horsley, F.R.C.S., F.R.S. (1857-1916). This great surgeon and neuro-physiologist was surgeon to University College Hospital and the National Hospital. It was here on 9 June 1887 that he was the first surgeon to remove a tumour from the spinal cord. The patient made an excellent recovery. As professor-superintendent of the Brown Institution he did work of fundamental importance, including $(a)$ the localization of function in the brain and the pathology of epilepsy and canine chorea; $(b)$ the thyroid gland and myxoedema and cretinism; and $(c)$ the protective treatment against rabies. In the latter connexion he was secretary of the British Commission of Inquiry which entirely confirmed Pasteur's discovery. Thereafter his research work on the physiology of the central nervous system and its practical application to surgery brought Horsley international fame. He died in Mesopotamia in 1916 while serving as a Colonel A.M.S. in the first world war, a hero's death of self-sacrifice, operating and teaching cerebral surgery to the very end.

I first met Sir Victor Horsley at the Annual Meeting of the British Medical Association held at Oxford in I904. After my Final Schools I had been assisting Dr. Gustav Mann in a research on the histology of the optic thalamus, and Sir Victor spoke in the discussion on Dr. Mann's paper. When he heard from his brother-in-law, Dr. Francis Gotch, my professor of physiology, that I was coming to University College Hospital as a medical student, he invited me to work with him in his laboratory. I had the privilege of assisting him in his researches from October, 1904 until the end of 1909 . The result of our cerebellar research, entitled 'Cervico-Spinal-Bulbar and Spino-Cerebellar Tracts and on the Question of Topographical Representation in the Cerebellum', was published in Brain in 1909."

To Horsley's laboratory came pioneers in neurology and surgery to see his experiments and to discuss his findings. In addition to Hughlings Jackson, Ferrier and Macewen, whom I have mentioned, I met there Kocher of Berne; Harvey Cushing, who honoured me with his friendship and entertained me at New Haven, Connecticut, three months before his death; and L. F. Barker of Johns Hopkins University. Here also I made friends of some of Sir Victor's past and present collaborators, such as J. Risien Russell, Sir Francis Teale, Sir Gordon Holmes, Page May, Donald Armour, Wilfred Harris, Colin K. Russel of Montreal, Ernest Sachs of Harvard and Dr. Bouché of Brussels. These men benefited in countless ways from Horsley's help and guidance and took high positions as neurologists or cerebral surgeons. All were inspired by Horsley's high ideals to give knowledge to mankind and to combat suffering and disease.

\section{Sir William Gowers}

Sir William Gowers, M.D.Lond., F.R.S. (1845-1915) was physician to University College Hospital and to the National Hospital. He was an acute 
clinical observer and a dogmatic teacher. When speaking, he opened his mouth very wide and the words of wisdom issued in deliberate, drawling, deep tones. White-haired, his yellow beard flecked with grey, with keen, searching eyes, and always wearing a frock coat, the discoverer of Gowers' Tract evoked respectful admiration.

Hughlings Jackson taught neurology as a philosopher, Gowers as a clinician. As Sir Charles Symonds said in the Sir William Gowers Memorial Lecture of 1960: 'It is to the fortunate association in the early days of the National Hospital of two men of genius so different in their outlook, yet alike in their aims, that we owe in large measure the tradition which has inspired their successors to this day.'

\section{H. C. Bastian}

Henry Charlton Bastian, M.A., M.D.Lond., F.R.S. (1837-1915) had retired from the medical staffs of University College Hospital and the National Hospital before I came to London. Primarily a pathologist-he obtained his F.R.S. for early work on parasitology - he became also a pioneer in neurology. From 1869 he studied aphasia (Lumleian Lectures, 1898 ) and wrote on other aspects of neurology. He devoted his declining years to spontaneous generation, affirming that a fortuitous concourse of atoms could give rise to life and that his experiments proved this. I heard him lecture on the subject but was not convinced. However, biochemists in the laboratory may eventually show that his views were not so visionary as they were considered.

\section{E. C. Beevor}

Charles Edward Beevor, M.D.Lond., F.R.C.P. (1854-1908) qualified in 1878. After holding house appointments at University College Hospital and the National Hospital, on his return from study abroad, he joined the medical staffs of the National and the Great Northern Hospitals. He was the first Dean of the National Hospital. A devoted friend and disciple of Victor Horsley, their joint work on cerebral localization made Beevor also famous as a neurophysiologist. His Handbook on Diseases of the Nervous System appeared in 1898; his Lettsomian Lectures to the Medical Society of London in 1907 were on the diagnosis and localization of cerebral tumours; his Croonian Lectures to the Royal College of Physicians in the same year on cerebral localization; and his description of the arterial supply to the brain (Phil. Trans., 1908), were all original and comprehensive.

Beevor was of middle height with carefully trimmed beard and moustache and kindly eyed. He was always gentle, unassuming, and modest about his own work. A regular attendant at Horsley's laboratory, he was ready to assist the experimental work in all possible ways. He and I spent much time together at the laboratory bench, cutting, staining and examining microscopical sections for Sir Victor. He had artistic and musical gifts. I was grieved to hear of his death in 1908 shortly after his return from a successful lecturing tour in America. 


\section{Sir Arthur MacNalty}

\section{Sir Fohn Rose Bradford}

Sir John Rose Bradford, Bart., K.G.M.G., G.B., G.B.E., M.D.Lond., P.R.G.P., F.R.S. (1863-1938) was the only son of Abraham Rose Bradford, deputy-inspector-general of Hospitals, R.N. I was his clinical clerk and housephysician at University College Hospital. He told me that as a child walking with his father along Oxford Street, he had seen a blind beggar in a white smock, led by a woman, and was informed that this man was the notorious Hare of the Burke and Hare murders in 1828 .

After qualifying from University College Hospital, Bradford soon became known for his physiological researches on the electrical phenomena accompanying secretion, the action of drugs on the circulation and secretion of the kidney, and his papers on these subjects. In 1889 he was elected to the medical staff of University College Hospital. He then contemplated specializing in neurology, and in 1893 became assistant physician to the National Hospital, but resigned in 1896 soon after his appointment as professor-superintendent of the Brown Institution, where he worked until 1903. By this date he was recognized as an expert on acute and chronic nephritis. He never sought private practice, and from 1897 devoted himself entirely to teaching, his hospitals and administrative work. He was senior medical adviser to the Colonial Office and served as a consultant physician with the rank of MajorGeneral, A.M.S. in the First World War.

If he had wished, he could have become a leading neurologist. He was specially good on cases of obscure nervous disease and their differential diagnosis. Hughlings Jackson had particularly impressed him and he often quoted from Jackson's papers. Bradford was one of the great physicians and teachers of all time.

\section{S. Risien Russell}

John Samuel Risien Russell, M.D.Edin., F.R.C.P. (1864-1939) after graduating at Edinburgh did post-graduate work at St. Thomas's Hospital, Paris (where he studied nervous diseases at the Salpetrière under Charcot) and Berlin. He was appointed physician to University College Hospital and the National Hospital. His early research with Victor Horsley was on the functions of the cerebellum. He also first described subacute combined degeneration of the spinal cord; and with his colleagues, F. E. Batten, M.D.Cantab. (1865I918) and J. S. Collier, M.D.Lond. (1870-1935) at Queen Square did much to elucidate the course and symptoms of this disease. I knew both Batten and Collier. Batten gave me his book on poliomyelitis and was interested in my early studies of epidemics of this disease.

Russell, a gifted and inspiring teacher, was expert in demonstrating the characteristic signs and symptoms in a patient. He showed some interesting and rather pathetic examples of cerebral syphilis in his ward here. I also remember he gave a wonderful demonstration to a large audience on a young woman with hystero-epilepsy, a form of convulsive hysteria, studied and described by Charcot, but a rare condition in this country. The patient showed the typical epileptoid phenomena with catalepsy, 'crucifixion attitudes', waxy 


\section{Some Pioneers of the Past in Neurology}

plasticity of the limbs, ecstasy, beatitude, erotism and hallucinations. These were demonstrated by Russell in a way which Charcot could hardly have surpassed. My last meeting with Russell was in 1939 when I was a guest at the University of Edinburgh Dinner in London, when we joined hands in singing 'Auld Lang Syne'. He died only a short time afterwards. He had a large private practice. The National Hospital will always be proud of the lustre his attainment shed upon it. Dr. Macdonald Critchley informs me that he was his last house-physician.

\section{W. Page May}

William Page May, M.D.Lond., F.R.C.P. (1863-19ro) was one of the happy fraternity of research workers in Horsley's laboratory. He was educated at University College and University College Hospital. After a distinguished academic career he was a resident at University College Hospital the National Hospital and other hospitals. His health broke down and he spent two years in Egypt, after which he was able to practise at Helouan during the winter months up to I 9o6. Each summer he came to England to research on neuro-physiology at University College. In 1903 the College appointed him lecturer (unpaid) in this subject. In 1906 he relinquished practice for teaching and research. Much of the latter was done in Horsley's laboratory. He discovered a tract of descending fibres in the posterior column of the cervical region of the spinal cord which received the name of 'May's Tract'.

May was of medium height, dark-haired with a black moustache. He died suddenly at Brighton in his forty-seventh year. Devoted to research on the central nervous system, May would have achieved greater fame as a neurological pioneer had his working capacity not been severely handicapped by ill-health.

\section{Two Famous Pioneers}

In latter years my friend, Sir Francis Walshe, M.D.Lond., F.R.S. has brilliantly maintained the traditional link between University College Hospital and the National Hospital. Two further famous pioneers in our knowledge of the physiology and pathology of the central nervous system were both University College Hospital men, but were not directly associated with the National Hospital.

Sir Frederick Walker Mott, K.B.E., M.D.Lond. (1853-1926) was one of Victor Horsley's fellow-students at University College Hospital. While still medical students Horsley and Mott published papers on bacteriology. In 1883 Mott was appointed assistant professor of physiology at Liverpool, but returned to London as lecturer in physiology at Charing Cross Hospital in 1884. This led to his appointment as physician from 1890 to 1913 at the Hospital. A good general physician he was also distinguished as a neurologist. $\mathrm{He}$ achieved further fame as neuro-pathologist to the London County Council Asylums, working in the laboratory at Claybury, and, afterwards, directing pathological research at the Maudsley Hospital and Birmingham University.

By 1905 Mott strongly suspected that syphilis had a protozoal origin, but 


\section{Sir Arthur MacNalty}

Schaudinn's discovery of the treponema pallida in that year anticipated him. Mott later proved that general paralysis of the insane was associated with the presence of this organism. His other researches on the pathology of the central nervous system are well known. Mott took great interest in the research work on the cerebellar tracts which I was doing with Horsley and was a good friend to me. He will always be remembered as a great neuro-pathologist.

Sir Henry Head, M.D.Cantab., F.R.S. ( $186 \mathrm{I}-1940)$, was educated at Charterhouse, Trinity College, Cambridge and University College Hospital. He became physician to the London Hospital. His experiments on himself on the sensory changes following section and regeneration of the radial and external cutaneous nerves were brilliant research work; and his M.D. thesis on Disturbances of Sensation with Especial Reference to the Pain of Visceral Diseases (Brain, 1893-96) heralded his recognition as an eminent neurologist. His last major work, Aphasia and Kindred Disorders of Speech, appeared in 1926.

I saw much of Head's work when I was a medical registrar at the London Hospital. A vivid and stimulating teacher, he was also a good showman of the effects of neurological disease on patients. The eliciting of some sign or eccentricity of behaviourism would make him jump about excitedly and his voice would rise to a falsetto pitch. I remember two American physicians expressing their appreciation after such a clinical demonstration. Head much pleased invited them to a further clinic on the following day. 'That's vurry kind of you, Dr. Head,' was the reply, 'but we've already booked seats for a show at the Hippodrome.'

It was tragically appropriate that Head should die of a nervous malady. He was stricken with Parkinson's disease, and noted his symptoms and the progress of his illness with characteristic scientific interest.

\section{S. A. K. Wilson and others}

S. A. Kinnier Wilson, M.D.Edin., F.R.C.P. (1874-1937), Physician to the National Hospital, assistant physician to Westminster Hospital, and later neurologist to King's College Hospital, was also neurologist to the London County Council. In I9I 2 he described the familiar nervous syndrome (hepatolenticular degeneration) that became known as 'Wilson's disease'. Wilson was interested in my investigations of encephalitis lethargica, and in after-years I met him in consultation over cases of epidemic poliomyelitis in the London County Council Hospitals. His satirical manner cloaked a sensitive and kindly nature, as it was my good fortune to know.

Other neurologists I can do little more than mention today. For instance J. A. Ormerod, M.D.Oxon., F.R.C.P. (1849-1925); H. H. Tooth, G.B., C.M.G., M.D.Cantab., F.R.C.P. (1858-1926) of Charcot-Marie-Tooth fame; Sir Gordon Holmes, G.M.G., G.B.E., M.D.Dublin, F.R.S., a friend since the days he was R.M.O. here and happily still with us; T. Grainger Stewart, M.D.Edin., F.R.C.P.; G. M. Hinds-Howell, M.D.Oxon., F.R.C.P. (18771960); Sir Geoffrey Jefferson, F.R.S., who trod in Horsley's foot-steps as a great neuro-surgeon and neuro-physiologist; and J. G. Greenfield, the pathologist. Another great neuro-surgeon, who died too early, was the lovable Sir

$$
256
$$




\section{Some Pioneers of the Past in Neurology}

Hugh Cairns of Oxford who worked with me during the last war and afterwards. In the study of neurology I profited by these men's wisdom and valued their friendship.

EPIDEMIC DISEASES OF THE CENTRAL NERVOUS SYSTEM

When I became in I914 a medical inspector of the Local Government Board I imagined that I had said goodbye to neurological research. It was not so. In August of that year the First World War began and I was seconded to the War Office as Medical Inspector of Camps and Hospitals. Towards the end of the year the Canadian troops introduced a virulent strain of the meningococcus and (from 1914-8) 6,450 cases of cerebro-spinal fever were notified in England and Wales; 4,238 military cases occurred in this country during the same period. I worked with Sir Shirley Murphy and Colonel R. J. Reece studying the epidemiology and clinical features of the epidemic and I helped Reece in his article on the disease for the Medical History of the War. ${ }^{5}$ The death-rate was high, averaging 72 per cent, a contrast with the severe epidemic of $194^{-}-3$, when sulphonamide therapy greatly reduced the case-mortality.

\section{AGUTE POLIOMYELITIS}

I was also employed in investigating several epidemics of poliomyelitis for the Local Government Board and the Ministry of Health. My Reports to these departments confirmed Wickman's findings on contact infection and a further account will be found in my Milroy Lectures to the Royal College of Physicians (1925). ${ }^{6} \mathrm{I}$ am glad I have lived to see the diminution and prevention of this crippling disease by vaccine-therapy.

\section{ENCEPHALITIS LETHARGIGA}

From March to April I918, a number of cases of an obscure disease, characterized usually by stupor or lethargy and ophthalmoplegia were reported in England. Early attention was directed to the subject by W. Harris and by A. J. Hall. A detailed investigation of the outbreak was made by the Local Government Board and the Medical Research Council, Professor J. McIntosh and Professor Marinesco of Bucharest studying the pathology, Colonel S. P. James, F.R.S., the epidemiology, while I was responsible for the field investigations and the clinical aspect of the inquiry. In studying the disease in hospitals I was helped by Sir William Osler at Oxford, by Sir Arthur Hall at Sheffield, by physicians at the National Hospital, by Sir Henry Head at the London Hospital and by E. G. Fearnsides at the Maida Vale Hospital. All these eminent physicians gave me access to patients with 'the new disease' in their hospital wards and allowed me to make free use of their clinical notes for my inquiry. We investigators arrived independently at the same conclusion, namely, that the new disease was anatomically and clinically distinct from analogous infections such as polioencephalitis and constituted a clinical entity. Kinnier Wilson and Buzzard early adduced evidence supporting our conclusions. Later, when the foreign medical journals came through, we were in a position to add that the disease as it appeared in the English outbreak was 


\section{Sir Arthur MacNalty}

identical with encephalitis lethargica, described by von Economo in Vienna and by Netter in Paris. Our findings were recorded in a special report to the Local Government Board (bluebook) in $1918 ;^{7}$ it was the first detailed description in English of encephalitis lethargica. Osler gave me full credit in his last edition of his text-book of Medicine, as did Sir Arthur Hall in his Lumleian Lectures (1924) on Epidemic Encephalitis; ${ }^{8}$ and Kinnier Wilson quoted my findings at length in his work Neurology, published posthumously in 1940. In I920 I investigated and reported to the Ministry of Health on a remarkable epidemic of encephalitis lethargica in a Girls' Home at Derby. ${ }^{9}$ From this virulent and intensive outbreak I obtained pathological material with which $H$. M. Turnbull and J. McIntosh at the London Hospital succeeded in reproducing the disease in monkeys. ${ }^{10}$ Unfortunately, the strain of the virus died out. I continued to investigate this disease and its tragic sequelae, especially cases of Parkinsonism. I also adduced evidence that Epidemic Hiccup was a mild or frustrated form of the malady. The disease has greatly diminished but cases with the characteristic lethargy occur from time to time, as in the Colchester outbreak of I962. Only recently Lord Brain showed me patients under his care in the London Hospital which presented similar symptoms and signs to those which I identified in the epidemic of 1918 . It is therefore particularly interesting for me to note that powerful psychotropic drugs like those of the phenothiazine group produce effects very similar to those we saw as sequelae of encephalitis lethargica, for instance, lethargy, abnormal movement of choreiform type, respiratory disturbances and Parkinsonism; and that they may persist as they did in our cases.

\section{Conclusion}

In preparing this Lecture I was asked to give some account of my own work in neurology. This I have done in order to show how greatly my masters and teachers have helped me. I thank you for giving me this opportunity to pay my tribute to the National Hospital.

Neurology marches on and the eminent successors to the pioneers of the past by modern methods are discovering and will garner further knowledge of the central nervous system. You who serve under their banners will not be unmindful of the pioneers who well and truly laid the foundations of neurology on which they and you are building today.

\section{REFERENCES}

I. Goody, W., Some aspects of the life of Dr. C. E. Brown-Séquard, Proc. roy. Soc. Med., 1964, 67, 189-196.

2. Sy monds, G., Disease of mind and disorder of brain, Brit. med. J., 1960, ii, I-5.

3. Gritchley, M., Jacksonian ideas and the future, with special reference to aphasia, Brit. med. J., 1960, ii, 6-12.

4. Horsley, V., and MacNalty, A. S., On the cervical spino-bulbar and spinal-cerebellar tracts and on the question of topographical representation in the cerebellum, Brain, 1909, 33, 237-255. 
5. ReEce, R. J., History of the Great War, Medical Services, Hygiene of the War, Prevention of Cerebro-Spinal Fever. London, H.M.S.O., 1923, ii, 280-281.

6. MacNalty, A. S., Epidemic Diseases of the Central Nervous System, London, Faber and Gwyer, 1927.

7. Report of an Enquiry into an Obscure Disease, Encephalitis Lethargica. Reps. to L.G.B. on Public Health and Medical Subjects, N.S. No. 12 I, London, H.M.S.O., 1918.

8. Hall, A. J., Epidemic Encephalitis, Bristol and London, 1924.

9. MacNalty, A. S., Report on Outbreak of Encephalitis Lethargica in a girls' home, Ann. Rep. of the Chief Medical Officer, Min. of Hith., 1919-20, appendix VII, London, H.M.S.O.

I0. MaINTOSH, J. and TURNBUlL, H. M., Experimental transmission of encephalitis lethargica to a monkey, Brit. J. exp. Pathol., 1920, 1, 89-102. 